\title{
Article \\ Genomic Analysis of Escherichia coli Longitudinally Isolated from Broiler Breeder Flocks after the Application of an Autogenous Vaccine
}

\author{
Liča Lozica ${ }^{1}$ (D), Kasper Rømer Villumsen ${ }^{2}\left(\mathbb{D}\right.$, Ganwu Li ${ }^{3,4}$, Xiao Hu ${ }^{4}$, Maja Maurić Maljković 5 \\ and Željko Gottstein $1, *$ (D)
}

check for

updates

Citation: Lozica, L.; Villumsen, K.R.;

Li, G.; Hu, X.; Maljković, M.M.;

Gottstein, Ž. Genomic Analysis of

Escherichia coli Longitudinally

Isolated from Broiler Breeder Flocks

after the Application of an

Autogenous Vaccine. Microorganisms 2022, 10, 377. https://doi.org/

10.3390/microorganisms10020377

Academic Editor: Kirill Sharshov

Received: 7 December 2021

Accepted: 3 February 2022

Published: 6 February 2022

Publisher's Note: MDPI stays neutral with regard to jurisdictional claims in published maps and institutional affiliations.

Copyright: (c) 2022 by the authors. Licensee MDPI, Basel, Switzerland. This article is an open access article distributed under the terms and conditions of the Creative Commons Attribution (CC BY) license (https:// creativecommons.org/licenses/by/ $4.0 /)$.
1 Department of Poultry Diseases with Clinic, Faculty of Veterinary Medicine, University of Zagreb, Heinzelova 55, 10000 Zagreb, Croatia; llozica@vef.unizg.hr

2 Department of Veterinary and Animal Sciences, Faculty of Health and Medical Sciences, University of Copenhagen, Dyrlægevej 88,1870 Copenhagen, Denmark; krv@sund.ku.dk

3 State Key Laboratory of Veterinary Biotechnology, Harbin Veterinary Research Institute, Chinese Academy of Agricultural Sciences, Harbin 150069, China; liganwu@iastate.edu

4 Department of Veterinary Diagnostic and Production Animal Medicine, College of Veterinary Medicine, Iowa State University, Ames, IA 50011, USA; xiaohu@iastate.edu

5 Department of Animal Breeding and Livestock Production, Faculty of Veterinary Medicine, University of Zagreb, Heinzelova 55, 10000 Zagreb, Croatia; mmauric@vef.unizg.hr

* Correspondence: gottstei@vef.unizg.hr; Tel.: +385-1239-0280

\begin{abstract}
Escherichia coli is the main bacterial cause of major economic losses and animal welfare issues in poultry production. In this study, we investigate the effect of an autogenous vaccine on E. coli strains longitudinally isolated from broiler breeder flocks on two farms. In total, 115 E. coli isolates were sequenced using Illumina technologies, and compared based on a single-nucleotide polymorphism (SNP) analysis of the core-genome and antimicrobial resistance (AMR) genes they carried. The results showed that SNP-based phylogeny corresponds to a previous multilocussequence typing (MLST)-based phylogeny. Highly virulent sequence types (STs), including ST117-F, ST95-B2, ST131-B2 and ST390-B2, showed a higher level of homogeneity. On the other hand, less frequent STs, such as ST1485, ST3232, ST7013 and ST8573, were phylogenetically more distant and carried a higher number of antimicrobial resistance genes in most cases. In total, 25 antimicrobial genes were detected, of which the most prevalent were $m d f(A)(100 \%)$, sit $A B C D(71.3 \%)$ and $\operatorname{tet}(A)$ $(13.91 \%)$. The frequency of AMR genes showed a decreasing trend over time in both farms. The highest prevalence was detected in strains belonging to the B1 phylogenetic group, confirming the previous notion that commensal strains act as reservoirs and carry more resistance genes than pathogenic strains that are mostly associated with virulence genes.
\end{abstract}

Keywords: Escherichia coli; colibacillosis; poultry; autogenous vaccine; whole-genome sequencing; SNP; AMR

\section{Introduction}

Escherichia coli (E. coli) is the main bacterial cause of major economic losses and animal welfare issues in poultry production [1,2]. Colibacillosis on poultry farms is controlled through vaccination programs, in addition to strict biosecurity standards and rigorous farm management [1]. There are several available commercial E. coli vaccines, but no vaccination procedure to date has proved to be highly efficacious due to the genetic diversity of the bacteria [1]. As the avian pathogenic E. coli (APEC) is closely related to other extraintestinal pathogenic E. coli (ExPEC) subpathotypes, which cause infections in the human population, colibacillosis in poultry also presents a danger to public health [2-8].

The localization and severity of the infection varies depending on the strain, site of entry and general health of the bird [1,9]. Usually, the most common lesions in adult 
birds are airsacculitis, peritonitis, salpingitis and septicaemia, although in egg laying hens, peritonitis, salpingitis and salpingitis-peritonitis syndrome (SPS) have been considered the most prevalent, as the infection usually occurs by bacteria ascending through the cloaca $[2,9-11]$.

Many studies have focused on the importance of certain virulence-associated genes (VAGs) and their role in the pathogenesis of E. coli infection [12-15]. The validation of specific sets of VAGs as definite predictors of E. coli virulence could help to improve the diagnostics process and enable quicker response during colibacillosis outbreaks. Currently, ColV plasmids are associated with the pathogenicity of E. coli and considered a defining trait of APEC [15-17]. However, Mageiros et al. (2021) have reported a high prevalence of the putative plasmid genes among both pathogenic and commensal E. coli strains in chickens, with a higher average number of plasmid genes per isolate in the commensal strains, suggesting that the virulence of $E$. coli is linked with the homologous sequence variations of the genes [18]. Several population genomics studies have detected signatures of adaptation to different hosts in the bacterial genomes, which are manifested as mutations or horizontal acquisition of genetic elements $[8,19,20]$. Additionally, the antimicrobial resistance (AMR) genes are often located on plasmids [21]. They are similarly easily acquired by horizontal transmission, which presents an additional growing concern for animal and human health [22].

Single-nucleotide polymorphisms (SNPs) are the most common form of genetic code variation in the genome [23]. They are considered the most useful biomarkers for disease diagnosis and prognosis because they can influence the rate of the disease progression and immune response of the host [23]. They can also be used to track transmission, predict important phenotypes of the bacteria and monitor disease outbreaks [24]. The aim of this study is to investigate the heterogeneity of the isolates using SNP analysis and to detect the prevalence and horizontal transmission of AMR genes between and within flocks on two broiler breeder farms after the application of the autogenous vaccine.

\section{Material and Methods}

\subsection{Study Design}

This study is a continuation of previous research on E. coli gene variability after the application of the autogenous vaccine [25]. While the previous study was focused on the frequency of virulence-associated genes and MLST, the focus of the present study was on the use of SNPs for the phylogenetic analysis and the effect of the autogenous vaccine on antimicrobial resistance gene prevalence.

Two broiler breeder farms that are part of the same company, Farm A and Farm $\mathrm{B}$, with four and five flocks, respectively, were selected for the longitudinal research on E. coli gene variability after the application of the autogenous vaccine. The selected farms reported continuous problems with colibacillosis despite the regular use of commercial vaccines. From our suggestion, they started using an autogenous E. coli vaccine instead of the commercial vaccine, which proved to be successful [26]. Each flock was vaccinated with a specifically designed vaccine prepared from the strains isolated in the previous flock. In total, 115 E. coli strains originating from the flocks vaccinated with the commercial and/or autogenous vaccines were selected for whole-genome sequencing and further analyses (Table 1). 
Table 1. Description of E. coli vaccination programs and antimicrobial treatment data (rearing and production period) for each flock in this study ${ }^{1}$.

\begin{tabular}{|c|c|c|c|c|c|}
\hline Farm & Flock & $\begin{array}{l}\text { Number of Analysed } \\
\text { Strains per Flock }\end{array}$ & Vaccination & Age at the Time of Vaccination & Treatment \\
\hline \multirow{4}{*}{$\mathbf{A}$} & 1 & 10 & $\begin{array}{c}\text { Commercial vaccines } \\
\text { (live attenuated }+ \text { inactivated } 2 x)\end{array}$ & $\begin{array}{l}0 \mathrm{~d} \\
10 \mathrm{w} \\
18 \mathrm{w}\end{array}$ & Doxycycline \\
\hline & 2 & 14 & Autogenous vaccine $2 x$ & $\begin{array}{l}10 \mathrm{w} \\
18 \mathrm{w}\end{array}$ & Doxycycline, tiamulin \\
\hline & 3 & 13 & Autogenous vaccine $2 x$ & $\begin{array}{l}12 \mathrm{w} \\
19 \mathrm{w}\end{array}$ & - \\
\hline & 4 & 14 & Autogenous vaccine $2 x$ & $\begin{array}{l}10 \mathrm{w} \\
19 \mathrm{w}\end{array}$ & $\begin{array}{l}\text { Amoxicillin, doxycycline, } \\
\text { enrofloxacin, oxytetracycline }\end{array}$ \\
\hline \multirow{5}{*}{ B } & 1 & 13 & $\begin{array}{c}\text { Commercial vaccines } \\
\text { (live attenuated }+ \text { inactivated } 2 x)\end{array}$ & $\begin{array}{l}0 \mathrm{~d} \\
13 \mathrm{w} \\
19 \mathrm{w}\end{array}$ & Doxycycline, enrofloxacin, tylosin \\
\hline & 2 & 7 & $\begin{array}{l}\text { Commercial vaccines } \\
\text { (live attenuated } 2 x) \\
\text { Autogenous vaccine } 2 x\end{array}$ & $\begin{array}{c}0 \mathrm{~d} \\
5 \mathrm{w} \\
11 \mathrm{w} \\
18 \mathrm{w}\end{array}$ & Amoxicilllin, polymyxin E, tylosin \\
\hline & 3 & 15 & Autogenous vaccine $2 x$ & $\begin{array}{c}9 w \\
20 w\end{array}$ & Doxycycline, polymyxin E \\
\hline & 4 & 16 & Autogenous vaccine $2 x$ & $\begin{array}{l}10 \mathrm{w} \\
18 \mathrm{w}\end{array}$ & Doxycycline, enrofloxacin \\
\hline & 5 & 13 & Autogenous vaccine $2 x$ & $\begin{array}{c}9 w \\
17 w\end{array}$ & Amoxicillin, enrofloxacin \\
\hline
\end{tabular}

1 adapted from Lozica et al., 2021.

\subsection{Bacterial Strain Selection and DNA Isolation}

Bacterial strain selection, DNA isolation and sequencing were previously described in more detail [25]. Briefly, 115 E. coli strains were isolated from the daily mortalities diagnosed with colibacillosis. The carcasses were routinely subjected to the pathomorphological examination as a part of the health surveillance or during outbreaks. The strains were recovered from the birds with lesions consistent with colibacillosis and selected for wholegenome sequencing based on the tissue of origin and age of the birds. Target organs were the peritoneum, liver, oviduct, and bone marrow, as they are often severely affected by colibacillosis. In case the strains from targeted tissues were not available, strains from other organs, such as lungs and the pericardium, were selected. The strains originated from birds older than 21 weeks, when outbreaks caused by colibacillosis usually emerge. Three or more strains per flock used for the vaccine production were also sequenced and included in the analyses. DNA was isolated as previously described [25] and stored at $-20^{\circ} \mathrm{C}$ until further analyses. The isolates used in this study are described in Supplementary Table S1.

\subsection{DNA Sequencing and Deposition}

Sequencing libraries were created based on the Illumina technologies, following the manufacturer's recommendations. Afterwards, whole-genome sequencing was conducted using MiSeq (Illumina, San Diego, CA, USA) with paired-end $250 \mathrm{bp}$ for 40 isolates, and NovaSeq 6000 platform (Novogene Co., Ltd., Beijing, China) with paired-end $150 \mathrm{bp}$ strategy for the remaining 75 isolates. The whole-genome sequences analyzed in this study were deposited in the National Center for Biotechnology Information (NCBI) as a BioProject under the accession number PRJNA681385.

\subsection{Phylogenetic Analysis}

SPAdes (v3.13.1) was used to assemble the raw reads of the 115 E. coli isolates to generate 115 draft genomes. Parsnp (v1.2) was used to construct the SNP tree, including 115 draft genomes and reference genomes, which were chosen based on their genetic diversity. In total, 19 reference genomes belonging to different phylogenetic groups and STs were included in this analysis [27]. All other genomes were aligned to the genome 
of the isolate B4, one of the input 115 sequences, to detect core SNPs and generate the core-genome SNP tree [28] by using Parsnp (Supplementary Table S2).

\subsection{Antimicrobial Resistance Gene Analysis}

For the analysis of the AMR genes, raw reads were assembled and trimmed using Assembler v1.2. [29]. Acquired antimicrobial resistance genes were detected using ResFinder v4.1. [30], and the assembled genomes were analysed with $90 \%$ ID and $60 \%$ minimum length threshold.

\subsection{Statistical Analysis}

The statistical analyses were performed in Statistica 13.2.0.17. (TIBCO Software Inc., Tulsa, OK, USA) and R 4.0.5. (R Core Team, Vienna, Austria). The results were tested for normality of data distribution using the Kolmogorov-Smirnov test. The statistical significance of differences in the frequency of AMR genes between and within both farms was analysed using the Kruskal-Wallis test, with statistical significance set at level $p \leq 0.05$. Poisson regression analysis was used to calculate the incident rate, standard error (SE) and 95\% confidence intervals (95\% CI) between the antimicrobial treatment and AMR gene prevalence among different flocks.

\section{Results and Discussion}

The results of the phylogenetic analysis correspond to the MLST-based phylogeny from the previous research (Figure 1) [25]. Isolates belonging to identical STs and phylogenetic groups were distributed both within the same and adjacent phylogroups in the phylogenetic tree based on the core-genome SNP clustering. Highly pathogenic strains, including ST117F, ST95-B2, ST131-B2, and ST390-B2, formed larger clusters and showed higher homogeneity between the isolates originating from the same farm. This indicates their possible resistance to vaccination, despite continuous inclusion in the vaccine, and longitudinal spread to the consecutive flocks, but with reduced general clinical implications and improved production traits on Farm B. Additionally, ST117-F clustered together regardless of the flock or farm of origin, which has already been observed and explained by the mutual origin of the strains from the grandparent flocks or from the shared rearing houses [25,31]. ST162 and ST23 formed separate clusters and were detected only on Farm A. Both STs included a variety of phylogenetic groups of which most are considered commensal, although they have previously been isolated from both diseased and healthy poultry [32-34]. Vaccination on Farm A significantly influenced the selection of strains in the consecutive flocks, but also showed to be non-protective against the heterologous strains. As the majority of the strains on Farm A were low pathogenic, they were probably more easily controlled by vaccination compared to Farm B, where the majority of the strains were more pathogenic and the phylogroup B2 resisted vaccination. SNP genotyping generally reveals a more detailed clonal relationship between the investigated isolates [9]. In our study, it showed slightly more discriminatory results compared to the MLST-based phylogeny, showing distribution of several isolates with the same ST in adjacent clusters based on the core SNPs. The strains belonging to less frequent STs, such as ST1485, ST3232, ST7013 and ST8573, were phylogenetically more distant and usually clustered separately. However, their average number of detected AMR genes was variable, mostly depending on the phylogenetic group. 


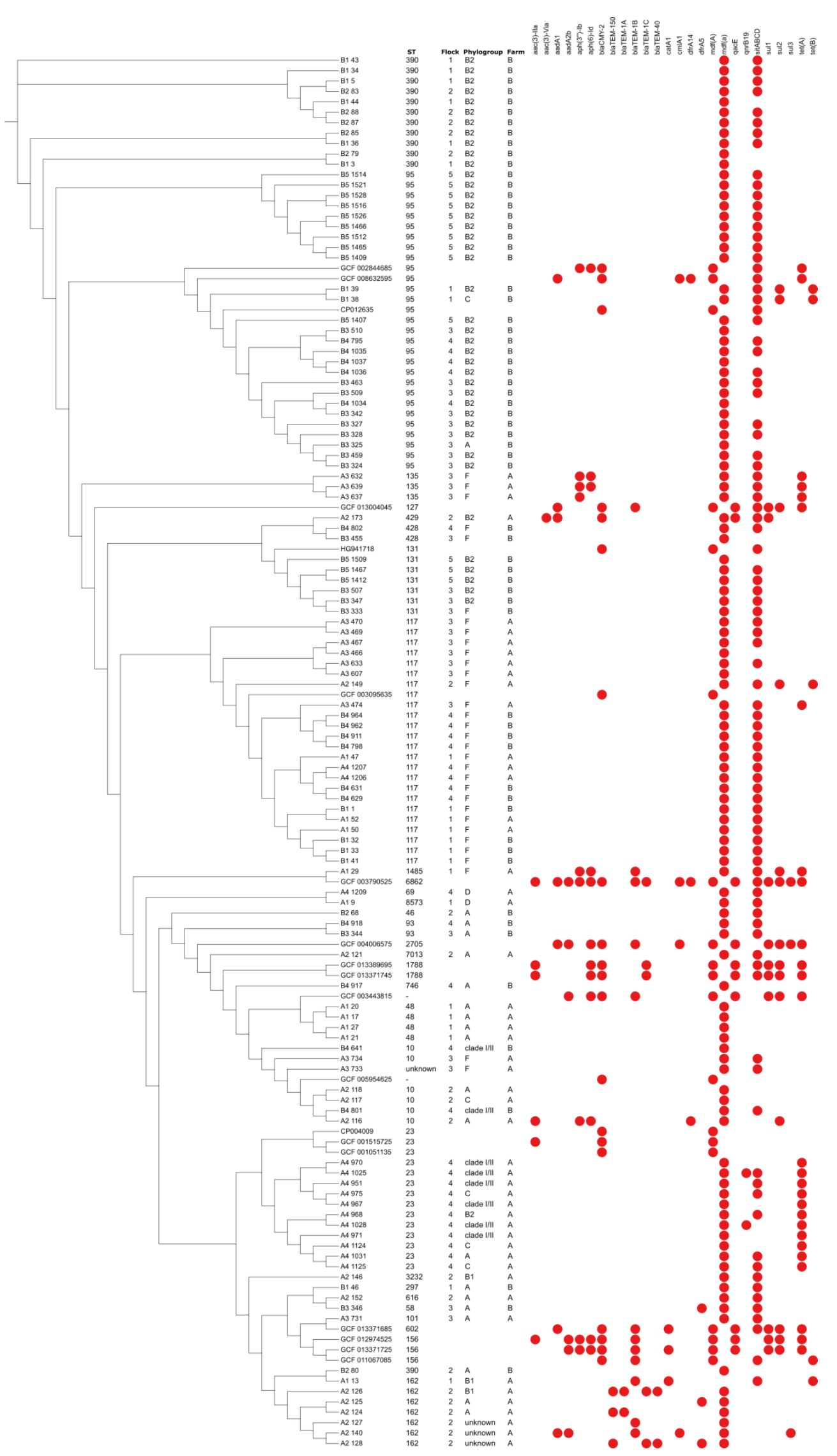

Figure 1. SNP-based phylogenetic tree showing distribution of AMR genes among 115 E. coli sequences. The analysis includes 19 reference E. coli genomes representing different STs and phylogenetic groups. 
We identified 25 AMR genes, of which $m d f(A)$ and sit $A B C D$ showed the highest prevalence on both farms (Table 2). Although $\operatorname{mdf}(A)$ has a broad-spectrum specificity, which includes six classes of antimicrobials, the phenotypes and the level of resistance it provides is unclear. Previous studies reported that $\operatorname{mdf}(A)$ encodes for a multidrug efflux pump and its expression confers multidrug resistance in E. coli, indicating that resistance could have occurred in isolates where we did not detect corresponding resistance genes $[35,36]$. Similar results were reported by Rafique et al. (2020), who detected the $m d f(A)$ gene in all 92 investigated E. coli strains isolated from chickens in different Pakistani provinces [22].

Table 2. Prevalence of the identified acquired AMR genes $(n(\%))$.

\begin{tabular}{|c|c|c|c|c|}
\hline AMR Gene & Phenotype & $\begin{array}{l}\text { Number of AMR Genes on Farm A * } \\
\qquad n=51\end{array}$ & $\begin{array}{l}\text { Number of AMR Genes on Farm B ** } \\
\qquad n=64\end{array}$ & Total Number of AMR Genes \\
\hline$a a c(3)-I I a$ & $\begin{array}{l}\text { apramycin, gentamicin, } \\
\text { tobramycin, dibekacin, } \\
\text { netilmicin, sisomicin }\end{array}$ & $1(1.96)$ & 0 & $1(0.87)$ \\
\hline$a a c(3)-V I a$ & gentamicin & $1(1.96)$ & 0 & $1(0.87)$ \\
\hline aadA1 & spectinomycin & $2(3.92)$ & 0 & $2(1.74)$ \\
\hline$a a d A 2 b$ & spectinomycin, streptomycin & $1(1.96)$ & 0 & $1(0.87)$ \\
\hline $\operatorname{aph}\left(3^{\prime \prime}\right)-I b$ & streptomycin & $5(9.8)$ & 0 & $5(4.35)$ \\
\hline $\operatorname{aph}(6)-I d$ & streptomycin & $5(9.81)$ & 0 & $5(4.35)$ \\
\hline$b l a_{\mathrm{CMY}-2}$ & $\begin{array}{l}\text { amoxicillin, amoxicillin + } \\
\text { clavulanic acid, ampicillin, } \\
\text { ampicillin + clavulanic acid, } \\
\text { cefotaxime, cefotxitin, } \\
\text { ceftazidime, piperacillin, } \\
\text { piperacillin + tazobactam, } \\
\text { ticarcillin, ticarcillin + } \\
\text { clavulanic acid } \\
\text { amoxicillin, ampicillin, }\end{array}$ & $1(1.96)$ & 0 & $1(0.87)$ \\
\hline$b l a_{\text {TEM-1A }}$ & $\begin{array}{l}\text { cephalothin, piperacillin, } \\
\text { ticarcillin } \\
\text { amoxicillin, ampicillin, }\end{array}$ & $3(5.88)$ & 0 & $3(2.61)$ \\
\hline$b l a_{\mathrm{TEM}-1 \mathrm{~B}}$ & $\begin{array}{l}\text { cephalothin, piperacillin, } \\
\text { ticarcillin }\end{array}$ & $4(7.84)$ & 0 & $4(3.48)$ \\
\hline$b l a_{\text {TEM-1C }}$ & $\begin{array}{l}\text { amoxicillin, ampicillin, } \\
\text { cephalothin, piperacillin, } \\
\text { ticarcillin }\end{array}$ & $2(3.92)$ & 0 & $2(1.74)$ \\
\hline$b l a_{\mathrm{TEM}-40}$ & $\begin{array}{l}\text { amoxicillin, amoxicillin }+ \\
\text { clavulanic acid, ampicillin, } \\
\text { ampicillin + clavulanic acid, } \\
\text { piperacillin, piperacillin }+ \\
\text { tazobactam, ticarcillin, } \\
\text { ticarcillin + clavulanic acid }\end{array}$ & $2(3.92)$ & 0 & $2(1.74)$ \\
\hline$b l a_{\mathrm{TEM}-150}$ & unknown beta-lactam & $3(5.88)$ & 0 & $3(2.61)$ \\
\hline cat $A 1$ & chloramphenicol & $1(1.96)$ & 0 & $1(0.87)$ \\
\hline cmIA1 & chloramphenicol & $1(1.96)$ & 0 & $1(0.87)$ \\
\hline$d f r A 5$ & trimethoprim & $2(3.92)$ & $1(1.56)$ & $3(2.61)$ \\
\hline$d f r A 14$ & $\begin{array}{l}\text { trimethoprim } \\
\text { unknown macrolide, }\end{array}$ & $1(1.96)$ & 0 & $1(0.87)$ \\
\hline$m d f(A)$ & $\begin{array}{l}\text { aminoglycoside, tetracycline, } \\
\text { fluoroquinolone, phenicol } \\
\text { and rifamycin }\end{array}$ & $51(100)$ & $64(100)$ & $115(100)$ \\
\hline$q a c E$ & $\begin{array}{c}\text { benzylkonium chloride, } \\
\text { ethidium bromide, } \\
\text { chlorhexidine, } \\
\text { cetylpyridinium }\end{array}$ & $1(1.96)$ & 0 & $1(0.87)$ \\
\hline qnrB19 & ciprofloxacin & $2(3.92)$ & 0 & $2(1.74)$ \\
\hline sit $A B C D$ & hydrogen peroxide & $31(60.78)$ & $51(79.69)$ & $82(71.3)$ \\
\hline sul1 & sulfamethoxazole & $1(1.96)$ & 0 & $1(0.87)$ \\
\hline sul2 & sulfamethoxazole & $3(5.88)$ & $2(3.13)$ & $5(4.35)$ \\
\hline sul3 & sulfamethoxazole & $1(1.96)$ & 0 & $1(0.87)$ \\
\hline $\operatorname{tet}(A)$ & doxycycline, tetracycline & $17(33.33)$ & 0 & $17(14.78)$ \\
\hline $\operatorname{tet}(B)$ & $\begin{array}{l}\text { doxycycline, tetracycline, } \\
\text { minocycline }\end{array}$ & $2(3.92)$ & $2(3.13)$ & $4(3.48)$ \\
\hline
\end{tabular}

$*$ ** Statistically significant difference in AMR gene frequency was detected between the farms $(p \leq 0.01)$.

The Sit $A B C D$ system mediates the transport of iron and manganese. Its ability to obtain manganese contributes to the resistance to oxidative stress and protection against agents such as hydrogen peroxide [37]. Additionally, sit operon genes are often associated with clinical infections caused by ExPEC, and have a contributing role as virulence factors by mediating the metal ion transport $[37,38]$. ResFinder analyses of our isolates discovered multiple copies of sit $A B C D$ genes. Previous phylogenetic analyses of the sit operon originating from E. coli and Shigella flexneri revealed they are most likely acquired by 
several distinct genetic events involving horizontal gene transfer [38]. Said events probably contributed to the presence of multiple gene copies in a single isolate, from which some are plasmid borne, and some are carried on chromosomes, and led to their high occurrence in E. coli populations $[16,38]$.

The gene $\operatorname{tet}(A)$ showed relatively high prevalence $(13.91 \%)$, although it was detected only on Farm A and predominantly in Flock 4 (68.75\%). The prevalence was probably a result of doxycycline application, which is commonly used as treatment for various bacterial poultry diseases. The dominance of tet $(A)$ out of different tetracycline resistance genes was reported in $E$. coli isolated from chickens and several other animal species, as opposed to the strains isolated from humans where tet(B) was more prevalent [39-42].

Interestingly, mobilized colistin resistance $(\mathrm{mcr})$ gene was not detected, although colistin (polymyxin E) has been used as antibiotic treatment on the studied farms (Table 1). It has been widely used to treat colibacillosis and as a growth promoter in the poultry industry for a long time $[1,43,44]$. Since polymyxins have been reintroduced as treatment for infections in humans and their application can influence the antimicrobial selective pressure [45], its use in veterinary medicine has been minimized [44].

The frequency of AMR genes decreased over time on both farms, with a more apparent change on Farm A (Figure 2A). When considering the phylogenetic groups of the analysed isolates, the results showed the highest prevalence of AMR genes in the B1 phylogroup and strains belonging to untypeable phylogenetic groups (Figure 2B). The high prevalence of resistance genes in phylogroup B1 confirms the notion that commensal strains act as reservoirs of AMR genes. Previous studies indicated that commensal strains carry more AMR genes, as opposed to pathogenic strains that usually possess more virulence factors, but are more susceptible to antimicrobials [46,47]. This concept was confirmed by this study by the significantly higher frequency of AMR genes on the Farm A (Table 2), in addition to our previous study, which showed a significantly lower average frequency of VAGs on Farm A than on Farm B [25]. The strains of unknown phylogenetic groups were identified as ST162 (Supplementary Table S1). As other detected ST162 strains were identified as the A or B1 phylogenetic group, we assume that untypeable strains were variations of said commensal phylogroups, further confirming the highest prevalence of AMR genes in the commensal strains. Overall, the average number of AMR genes per isolate was 2.71 and 1.87 on Farm A and $\mathrm{B}$, respectively, and there was no statistical significance in the prevalence of resistance genes between and within different studied flocks. The antimicrobial susceptibility testing of strains on the Farm A and B showed continuous decrease in resistance, especially on Farm A (unpublished data), which is consistent with the AMR gene results.

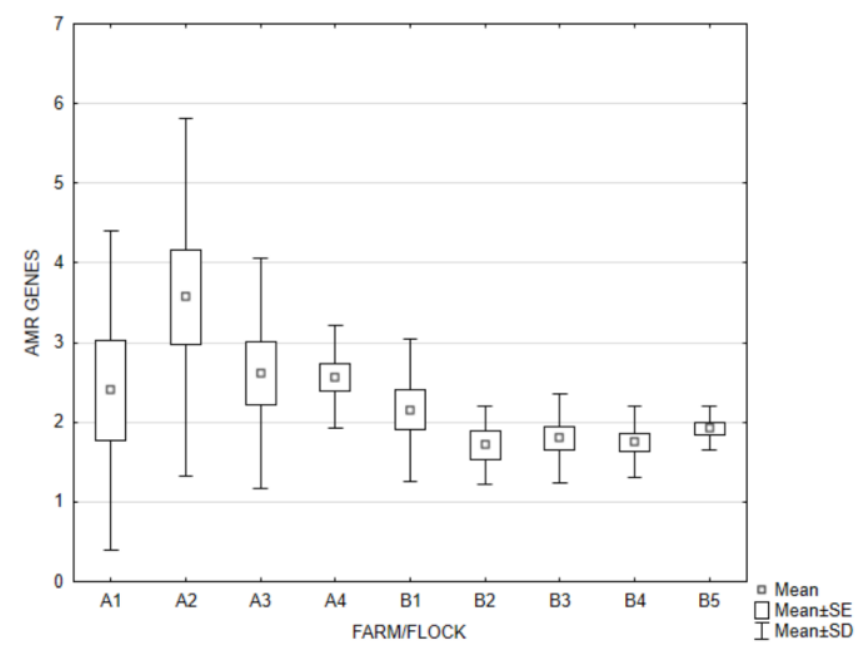

A

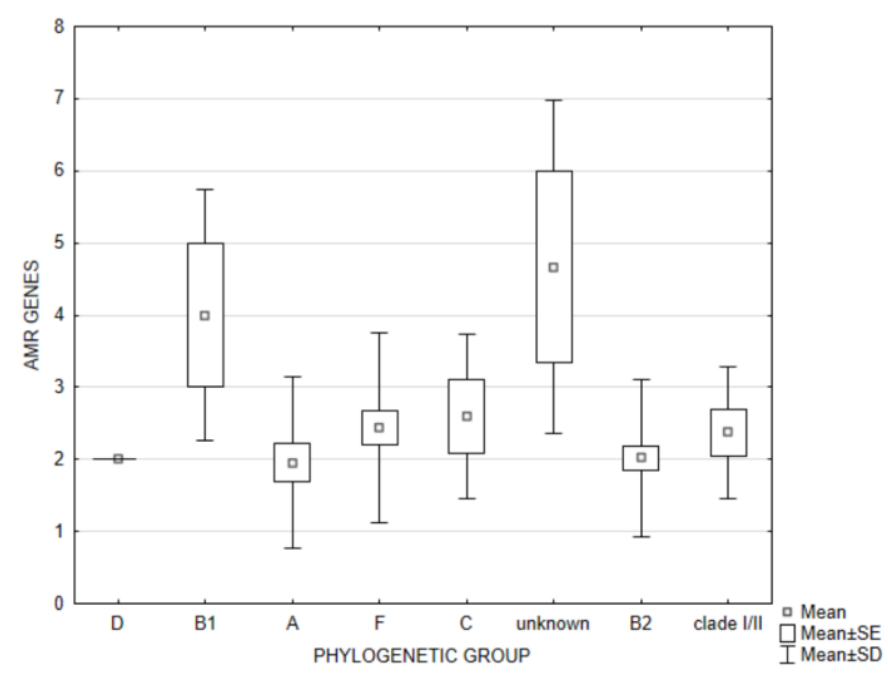

B

Figure 2. AMR gene frequency per flock on each farm (A) and per each detected phylogenetic group (B). 
The results showed the treatment with antimicrobials possibly affected the prevalence of certain E. coli strains, in addition to the effect of autogenous vaccine application [48], although there was no correlation between the antimicrobials used in the flocks and the detected AMR genes (Supplementary Table S3). The implementation of the autogenous vaccine induced genetic homogenization of the isolates [26,48], which increased the selection pressure and alleviated the management of colibacillosis on the investigated farms. The present results correspond to previous studies, which reported that the application of autogenous vaccines alone or in combination with a commercial vaccine serves well as a preventive measure on poultry farms [49-51]. The results showed a probable positive interaction of the autogenous vaccine and antimicrobial treatment, which could have reduced the overall prevalence of AMR genes on the farms in the long term. The antimicrobials and the vaccine possibly interacted and formed a more powerful selection mechanism where strains with AMR genes, if not removed by treatment, could be controlled by the immune system. In addition, on the investigated farms, vaccination with autogenous vaccines reduced the need for treatment with antimicrobials, therefore the stimulation and emergence of resistant $E$. coli strains significantly decreased.

\section{Conclusions}

Genomic analysis showed that both MLST and SNP-based phylogeny can provide a detailed characterization of E. coli strains, taking into consideration their virulence and overall genetic relatedness. Although none of the STs or phylogenetic groups could be associated with specific AMR genes, strains belonging to more uncommon STs and commensal phylogenetic groups carried more AMR genes in most cases. The results showed the highest prevalence of $m d f(A)$ and sit operon genes, which provide a wide-spectrum protection, indicating that the bacterial population was adapted over time by carrying less specialized genes. The autogenous vaccine induced the lower heterogeneity of the strains and possibly interacted with the antimicrobial treatment leading to the selection of strains with a lower amount of AMR genes over time, which is consistent with previous research.

Supplementary Materials: The following supporting information can be downloaded at: https: //www.mdpi.com/article/10.3390/microorganisms10020377/s1, Table S1: Description of isolates used in this study. Isolates in bold were used for the production of autogenous vaccines for the next consecutive flock on the farm, Table S2: Description of reference genomes used for the SNP analysis, Table S3: The results of the Poisson regression analysis showing the incident rate, standard error (SE) and 95\% confidence intervals $(95 \% \mathrm{CI})$ between the antimicrobial treatment and AMR gene prevalence among different flocks.

Author Contributions: Conceptualization, L.L. and Ž.G.; Methodology, L.L., Ž.G. and K.R.V.; Software, X.H. and M.M.M.; Validation, X.H. and G.L.; Formal Analysis, L.L., X.H., M.M.M. and Ž.G.; Investigation, L.L. and Ž.G.; Resources, L.L., Ž.G., K.R.V., X.H. and G.L.; Data Curation, X.H., G.L. and K.R.V.; Writing — Original Draft Preparation, L.L.; Writing—Review and Editing, Ž.G., K.R.V. and G.L.; Visualization, X.H., L.L. and Ž.G.; Supervision, Ž.G.; Project Administration, Ž.G.; Funding Acquisition, Ž.G. All authors have read and agreed to the published version of the manuscript.

Funding: This study was partially supported by the University of Zagreb, Croatia, under Grant "Longitudinal epizootiological study of the virulence-associated genes by whole genome sequencing of the pathogens with the aim to improve biosafety measures and immunoprophylaxis programs on poultry farms".

Institutional Review Board Statement: This article does not contain any studies with human participants or animals performed by any of the authors and all research was conducted in an ethical and responsible manner. The study was approved by the institutional ethics committee according to the national Animal protection Act (OG 102/2017) (License: Class: 640-01/19-17/50, Reg no: 251-61-44-19-02).

Informed Consent Statement: The permission for sampling and further analysis of the samples were granted by the farm. 
Data Availability Statement: The whole-genome sequences analysed in this study are publicly available as BioProject under the accession number PRJNA681385.

Conflicts of Interest: The authors declare no conflict of interest.

\section{References}

1. Nolan, L.K.; Vaillancourt, J.-P.; Barbieri, N.L.; Logue, C.M. Colibacillosis. In Diseases of Poultry, 14th ed.; Swayne, D.E., Ed.; Wiley-Blackwell: Ames, IA, USA, 2020; pp. 770-860.

2. Poulsen, L.L.; Kudirkiene, E.; Jørgensen, S.L.; Djordjevic, S.P.; Cummins, M.L.; Christensen, J.P.; Christensen, H.; Bisgaard, M.; Thøfner, I. Whole genome sequence comparison of avian pathogenic Escherichia coli form acute and chronic salpingitis of egg laying hens. BMC Vet. Res. 2020, 16, 148. [CrossRef] [PubMed]

3. Rodriguez-Siek, K.; Giddings, C.W.; Doetkott, C.; Johnson, T.J.; Fakhr, M.K.; Nolan, L.K. Comparison of Escherichia coli isolates implicated in human urinary tract infection and avian colibacillosis. Microbiology 2005, 151, 2097-2110. [CrossRef]

4. $\quad$ Ewers, C.; Li, G.; Wilking, H.; Kießling, S.; Alt, K.; Antáo, E.M.; Laturnus, C.; Diehl, I.; Glodde, S.; Homeier, T.; et al. Avian pathogenic, uropathogenic, and newborn meningitis-causing Escherichia coli: How closely related are they? Int. J. Med. Microbiol. 2007, 297, 163-176. [CrossRef] [PubMed]

5. Moulin-Schouleur, M.; Répérant, M.; Laurent, S.; Brée, A.; Mignon-Grasteau, S.; Germon, P.; Rasschaert, D.; Schouler, C. Extraintestinal pathogenic Escherichia coli strains of avian and human origin: Link between phylogenetic relationships and common virulence patterns. J. Clin. Microbiol. 2007, 45, 3366-3376. [CrossRef]

6. Daga, A.P.; Koga, V.L.; Soncini, J.G.M.; de Matos, C.M.; Perugini, M.R.E.; Pelisson, M.; Kobayashi, R.K.T.; Vespero, E.C. Escherichia coli bloodstream infections in patients at a University hospital: Virulence factors and clinical characteristics. Front. Cell. Infect. Microbiol. 2019, 9, 191. [CrossRef]

7. Nolan, L.K.; Logue, C.M.; Barbieri, N.L. APEC: A global one health pathogen and the myths that complicate its control. In Proceedings of the XXIst World Veterinary Poultry Association Congress, Bangkok, Thailand, 16-20 September 2019; pp. 86-90.

8. Zhang, H.; Chen, X.; Nolan, L.K.; Zhang, W.; Li, G. Identification of host adaptation genes to extraintestinal pathogenic Escherichia coli during infection in different hosts. Infect. Immun. 2019, 87, e00666-19. [CrossRef]

9. Christensen, H.; Bachmeier, J.; Bisgaard, M. New strategies to prevent and control avian pathogenic Escherichia coli (APEC). Avian Pathol. 2021, 50, 370-381. [CrossRef]

10. Jordan, F.T.W.; Williams, N.J.; Wattret, A.; Jones, T. Observations on salpingitis, peritonitis and salpingoperitonitis in a layer breeder flock. Vet. Rec. 2005, 157, 573-577. [CrossRef]

11. Li, L.; Thøfner, I.; Christensen, J.P.; Ronco, T.; Pedersen, K.; Olsen, R.H. Evaluation of the efficacy of an autogenous Escherichia coli vaccine in broiler breeders. Avian Pathol. 2017, 46, 300-308. [CrossRef]

12. Rodriguez-Siek, K.; Giddings, C.; Doetkott, C.; Johnson, T.; Nolan, L. Characterizing the APEC pathotype. BMC Vet. Res. 2005, 36, 241-256. [CrossRef]

13. Dziva, F.; Stevens, M.P. Colibacillosis in poultry: Unravelling the molecular basis of virulence of avian pathogenic Escherichia coli in their natural hosts. Avian Pathol. 2008, 37, 355-366. [CrossRef]

14. Johnson, T.J.; Jordan, D.; Kariyawasam, S.; Stell, A.L.; Bell, N.P.; Wannemuehler, Y.M.; Fernández-Alarcón, C.; Li, G.; Tivendale, K.A.; Logue, C.M.; et al. Sequence analysis and characterization of a transferable hybrid plasmid encoding multidrug resistance and enabling zoonotic potential for extraintestinal Escherichia coli. Infect. Immun. 2010, 78, 1931-1942. [CrossRef]

15. de Oliveira, A.L.; Rocha, D.A.; Finkler, F.; De Moraes, L.B.; Barbieri, N.L.; Pavanelo, D.B.; Winkler, C.; Grassotti, T.T.; De Brito, K.C.T.; De Brito, B.G.; et al. Prevalence of ColV plasmid-linked genes and in vivo pathogenicity of avian strains of Escherichia coli. Foodborne Pathog. Dis. 2015, 12, 679-685. [CrossRef]

16. Johnson, T.J.; Siek, K.E.; Johnson, S.J.; Nolan, L.K. DNA sequence of a ColV plasmid and prevalence-encoded virulence genes among avian Escherichia coli strains. J. Bacteriol. 2006, 188, 745-758. [CrossRef]

17. Jørgensen, S.L.; Stegger, M.; Kudirkiene, E.; Lilje, B.; Poulsen, L.L.; Ronco, T.; Pires Dos Santos, T.; Kiil, K.; Bisgaard, M.; Pedersen, K.; et al. Diversity and population overlap between avian and human Escherichia coli belonging to sequence type 95. $m S p h e r e$ 2019, 4, e00333-18. [CrossRef]

18. Mageiros, L.; Méric, G.; Bayliss, S.C.; Pensar, J.; Pascoe, B.; Mourkas, E.; Calland, J.K.; Yahara, K.; Murray, S.; Wilkinson, T.S.; et al. Genome evaluation and the emergence of pathogenicity in avian Escherichia coli. Nat. Commun. 2021, 12, 765-767. [CrossRef]

19. Sheppard, S.K.; Guttman, D.S.; Fitzgerald, J.R. Population genomics of bacterial host adaptation. Nat. Rev. Genet. 2018, 19, 549-565. [CrossRef]

20. Mehat, J.W.; van Vliet, A.H.M.; La Ragione, R.M. The Avian Pathogenic Escherichia coli (APEC) pathotype is comprised of multiple distinct, independent genotypes. Avian Pathol. 2021, 50, 402-406. [CrossRef]

21. Aworh, M.K.; Kwaga, J.K.P.; Hendriksen, R.S.; Okolocha, E.C.; Thakur, S. Genetic relatedness of multidrug resistant Escherichia coli isolated from humans, chickens and poultry environments. Antimicrob. Resist. Infect. Control 2021, 10, 58. [CrossRef]

22. Rafique, M.; Potter, R.F.; Ferreiro, A.; Wallace, M.A.; Rahim, A.; Malik, A.A.; Siddique, N.; Abbas, M.A.; D’Souza, A.W.; Burnham, C.-A.D.; et al. Genomic characterization of antibiotic resistant Escherichia coli isolated from domestic chickens in Pakistan. Front. Microbiol. 2020, 10, 3052. [CrossRef] 
23. Vallejos-Vidal, E.; Reyes-Cerpa, S.; Rivas-Pardo, J.A.; Maisey, K.; Yañez, J.M.; Valenzuela, H.; Cea, P.A.; Castro-Fernandez, V.; Tort, L.; Sandino, A.M.; et al. Single-nucleotide polymorphisms (SNP) mining and their effect on the tridimensional protein structure prediction in a set of immunity-related expressed sequence tags (EST) in Atlantic salmon (Salmo salar). Front. Genet. 2020, 10, 1406. [CrossRef] [PubMed]

24. Bush, S.J.; Foster, D.; Eyre, D.W.; Clark, E.L.; De Maio, N.; Shaw, L.P.; Stoesser, N.; Peto, T.E.A.; Crook, D.W.; Walker, A.S. Genomic diversity affects the accuracy of bacterial single-nucleotide polymorphism-calling pipelines. Gigascience 2020, 9, giaa007. [CrossRef] [PubMed]

25. Lozica, L.; Repar, J.; Gottstein, Ž. Longitudinal study on the effect of autogenous vaccine application on the sequence type and virulence profiles of Escherichia coli in broiler breeder flocks. Vet. Microbiol. 2021, 259, 109159. [CrossRef] [PubMed]

26. Gottstein, Ž.; Lozica, L.; Horvatek Tomić, D.; Lukač, M.; Prukner-Radovčić, E.; Vlahek, M.; Dolenčić, N.; Glavak, Ž. Production parameters after autogenous APEC E. coli vaccine application and improvement of vaccination program in broiler breeder flock. In Proceeding of the Poultry Days 2019, Poreč, Croatia, 8-11 May 2019; Balenović, M., Ed.; Croatian Veterinary Institute: Zagreb, Croatia, 2019; pp. 98-103.

27. Chen, X.; Liu, W.; Li, H.; Yan, S.; Jiand, F.; Cai, W.; Li, G. Whole genome sequencing analysis of avian pathogenic Escherichia coli from China. Vet. Microbiol. 2021, 259, 109158. [CrossRef]

28. Treangen, T.J.; Ondov, B.D.; Koren, S.; Phillippy, A.M. The Harvest suite for rapid core-genome alignment and visualization of thousands of intraspecific microbial genomes. Genome Biol. 2014, 15, 524-538. [CrossRef]

29. Larsen, M.V.; Cosentino, S.; Rasmussen, S.; Friis, C.; Hasman, H.; Marvig, R.L.; Jelsbak, L.; Sicheritz-Pontén, T.; Ussery, D.W.; Aarestrup, F.M.; et al. Multilocus sequence typing of total genome sequenced bacteria. J. Clin. Microbiol. 2012, 50, $1355-1361$. [CrossRef]

30. Bortolaia, V.; Kaas, R.S.; Ruppe, E.; Roberts, M.C.; Schwarz, S.; Cattoir, V.; Philippon, A.; Allesoe, R.L.; Rebelo, A.R.; Florensa, A.F.; et al. ResFinder 4.0 for predictions of phenotypes from genotypes. J. Antimicrob. Chemother. 2020, 75, 3491-3500. [CrossRef]

31. Ronco, T.; Stegger, M.; Olsen, R.H.; Sekse, C.; Nordstoga, A.B.; Pohjanvirta, T.; Lilje, B.; Lyhs, U.; Andersen, P.S.; Pedersen, K. Spread of avian pathogenic Escherichia coli ST117 O78:H4 in Nordic broiler production. BMC Genom. 2017, 18, 13. [CrossRef]

32. Papouskova, A.; Masarikova, M.; Valcek, A.; Senk, A.; Cejkova, D.; Jahodarova, E.; Cizek, A. Genomic analysis of Escherichia coli strains isolated from diseased chicken in the Czech Republic. BMC Vet. Res. 2020, 16, 189-199. [CrossRef]

33. Ramadan, H.; Jackson, C.R.; Frye, J.G.; Hiott, L.M.; Samir, M.; Awad, A.; Woodley, T.A. Antimicrobial resistance, genetic diversity and multilocus sequence typing of Escherichia coli from humans, retail chicken and ground beef in Egypt. Pathogens 2020, 9, 357. [CrossRef]

34. Smolza, A.; Wami, H.; Dobrindt, U. Comparative genomics of emerging lineages and mobile resistomes of contemporary broiler strains of Salmonella Infantis and E. coli. Front. Microbiol. 2021, 12, 342. [CrossRef]

35. Edgar, R.; Bibi, E. MdfA, an Escherichia coli multidrug resistance protein with an extraordinarily broad spectrum of drug recognition. J. Bacteriol. 1977, 179, 2274-2280. [CrossRef]

36. Ong, K.H.; Khor, W.C.; Quek, J.Y.; Low, Z.X.; Arivalan, S.; Humaidi, M.; Chua, C.; Seow, K.L.G.; Guo, S.; Tay, M.Y.F.; et al. Occurrence and antimicrobial resistance traits of Escherichia coli from wild birds and rodents in Singapure. Int. J. Environ. Res. Public Health 2020, 17, 5606. [CrossRef]

37. Sabri, M.; Léveillé, S.; Dozois, C.M. A SitABCD homologue from an avian pathogenic Escherichia coli strain mediates transport of iron and manganese and resistance to hydrogen peroxide. Microbiology 2006, 152, 745-758. [CrossRef]

38. Sabri, M.; Caza, M.; Proulx, J.; Lymberopoulos, M.H.; Brée, A.; Moulin-Schouleur, M.; Curtiss, R., III; Dozois, C.M. Contribution of the SitABCD, MntH, and FeoB metal transporters to the virulence of avian pathogenic Escherichia coli O78 strain $\chi 7122$. Infec. Immun. 2008, 76, 601-611. [CrossRef]

39. Maynard, C.; Bekal, S.; Sanschagrin, F.; Levesque, R.C.; Brousseau, R.; Masson, L.; Larivière, S.; Harel, J. Heterogeneity among virulence and antimicrobial resistance gene profiles of extraintestinal Escherichia coli isolates of animal and human origin. J. Clin. Microbiol. 2004, 42, 5444-5452. [CrossRef] [PubMed]

40. Wilkerson, C.; Samadpour, M.; van Kirk, N.; Roberts, M.C. Antibiotic resistance and distribution of tetracycline resistance genes in Escherichia coli O157:H7 isolates from humans and bovines. Antimicrob. Agents Chemother. 2004, 48, 1066-1067. [CrossRef]

41. Seifi, S.; Khoshbakht, R. Prevalence of tetracycline resistance determinants in broiler isolated Escherichia coli in Iran. Br. Poult. Sci. 2016, 57, 729-733. [CrossRef]

42. Jahantigh, M.; Samadi, K.; Dizaji, R.E.; Salari, S. Antimicrobial resistance and prevalence of tetracycline resistance genes in Escherichia coli isolated from lesions of colibacillosis in broiler chickens in Sistan, Iran. BMC Vet. Res. 2020, 16, 267-272. [CrossRef] [PubMed]

43. Gharaibeh, M.H.; Shatnawi, S.Q. An overview of colistin resistance, mobilized colistin resistance genes dissemination, global responses, and the alternatives to colistin: A review. Vet. World 2019, 12, 1735-1746. [CrossRef] [PubMed]

44. Koutsianos, D.; Athanasiou, L.V.; Dimitriou, T.; Nikolaidis, M.; Tsadila, C.; Amoutzias, G.; Mossialos, D.; Koutoulis, K.C. Antibiotic resistance patterns and $m c r-1$ detection in avian pathogenic Escherichia coli isolates from commercial layer and layer breeder flocks demonstrating colibacillosis in Greece. Microb. Drug Resist. 2021, 27, 710-720. [CrossRef]

45. Massella, E.; Giacometty, F.; Bonilauri, P.; Reid, C.J.; Djordjevic, S.P.; Merialdi, G.; Bacci, C.; Fiorentini, L.; Massi, P.; Bardasi, L.; et al. Antimicrobial resistance profile and ExPEC virulence potential in commensal Escherichia coli of multiple sources. Antibiotics 2021, 10, 351. [CrossRef] 
46. Smith, J.L.; Fratamico, P.M.; Gunther, N.W. Extraintestinal pathogenic Escherichia coli. Foodborne Pathog. Dis. 2007, 4, 134-163. [CrossRef]

47. Chakraborty, A.; Saralaya, V.; Adhikari, P.; Shenoy, S.; Baliga, S.; Hegde, A. Characterization of Escherichia coli phylogenetic groups associated with extraintestinal infections in South Indian population. Ann. Med. Health Sci. Res. 2015, 5, 241-246. [CrossRef]

48. Lozica, L.; Ekert Kabalin, A.; Dolenčić, N.; Vlahek, M.; Gottstein, Ž. Phylogenetic characterization of avian pathogenic Escherichia coli strains longitudinally isolated from broiler breeder flocks vaccinated with autogenous vaccine. Poult. Sci. J. 2021, 100, 101079. [CrossRef]

49. Landman, W.J.M.; van Eck, J.H.H. The efficacy of inactivated Escherichia coli autogenous vaccines against the E. coli peritonitis syndrome in layers. Avian Pathol. 2017, 46, 658-665. [CrossRef]

50. Koutsianos, D.; Gantelet, H.; Franzo, G.; Lecoupeur, M.; Thibault, E.; Cecchinato, M.; Koutoulis, K.C. An assessment of the level of protection against colibacillosis conferred by several autogenous and/or commercial vaccination programs in conventional pullets upon experimental challenge. Vet. Sci. 2020, 7, 80. [CrossRef] [PubMed]

51. Koutsianos, D.; Athanasiou, L.V.; Spyropoulou, M.; Prentza, Z.; Dedousi, A.; Polizopoulou, Z.; Mossialos, D.; Koutoulis, K. Evaluation of hematological variables in layer pullets after vaccination and challenge with E. coli. Comp. Clin. Pathol. 2021, 30, 113-118. [CrossRef] 